\title{
Translating Indonesian Notarial Documents into English: \\ Issues and Its Strategies
}

\author{
I Wayan Ana \\ English Department, \\ Faculty of Letters, Warmadewa University, \\ Denpasar, Bali, Indonesia \\ ana.wayan@gmail.com \\ I Made Budiarsa \\ School of Postgraduate Studies \\ Udayana University \\ Denpasar, Bali, Indonesia
}

\author{
Ida Bagus Putra Yadnya \\ English Department, \\ Faculty of Arts, Udayana University, \\ Denpasar, Bali, Indonesia
}

Ida Ayu Made Puspani

School of Postgraduate Studies

Udayana University

Denpasar, Bali, Indonesia

\begin{abstract}
Notary deed is an authentic deed drawn up by or before a notary. As a legal document, notary deed is drawn up using Indonesian legal language. Due to many foreigners entering into notary deeds in Indonesia, translation of notary deeds into foreign languages (particularly English) is indispensable. This notary deed is normally translated by certified translators. The aims of this research are to find out the issues faced by the translators in translating notary deeds and the strategies applied to translate them. The data used for this research are taken from 10 (ten) notary deeds obtained from notary offices in charge in 4 (four) regencies and 1 (one) city. The ten notarial documents consist of 3 lease agreements, 2 powers of attorney, 2 prenuptial agreements and 3 affidavits. To find out the issues faced by the translators, questionnaires were given to the translators frequently translating notary deeds and to recognize the strategies used by the translators, comparative study was carried out to source and target language. Based on the result of analysis, it was found 2 causes producing issues to the translators: linguistic and non-linguistic issues. While strategies applied in translating notary deeds are literal translation, established translation, calque, transference, cultural translation and official translation in word level, while in sentence level, literal translation, transposition and adaptation translation were commonly applied.
\end{abstract}

Keywords-authentic deed; notary deed; legal system; certified translator;

\section{INTRODUCTION}

The advanced development of technology and information has changed various aspects of life, including human flows, business behavior and the world economy. With these developments, the legal field is required to be able to counterbalance; in this case, Indonesian law is required to be able to adapt the phenomenon of international cooperation, of which goal is for the sake of mutual prosperity. Indonesian Economic Laws should also be capable to anticipate the effects of new developments, as a result of globalization indicated by the increasingly thin boundaries between countries resulting from the development of information and technology. These new developments continuously enhance the link of the Indonesian economy to the world economy, so that the Indonesian economy could not close itself to the influence and demands of globalization. As the result, free competition and business activities will increase very tremendously. Those doing business in Indonesia are not only Indonesian but foreigners from all over the world. To promote this atmosphere, the government must prepare, and provide adequate facilities and infrastructure in various fields, particularly legal protection and legal certainty as well as human resources in legal field to attract foreign investors and investment in Indonesia.

Notary Public (Openbaar Ambtennar) is one of the public officers required by foreigners who intend to draw up notarial documents (agreement or contract). He must be professional as he is representing the state in carrying out his duties and social functions in drawing up notarial deeds in the form of "Authentic Act". Notarial deeds are made by the parties before a notary public as a means of obtaining legal protection and certainty regarding the rights and obligations as well as roles and functions of each party.

A notarial document (deed) as an authentic deed under the prevailing law in Indonesia shall be drawn up in Indonesian language. It emerges an issue for foreigners who are the parties to the notarial deed, not only to understand the contents of the document to be executed, but also to comprehend legal terminology in different language and legal system as well as culture. To settle these issues, a notary usually asks for the service of a certified translator to translate the deed. In this case the translator plays an important role to bridge the differences between the legal cultures and more particularly between legal systems (Kocbek, 2012) in rendering the message of the source language (SL) into the target language (TL) (Cao, 2007; Newmark, 1998). Translating a notarial deed is not an easy job as it is a legal document, it is determined not only by particular factors such as, different culture, linguistic and legal environment where this legal document is drawn up 
but on the target users having their own culture and knowledge (Gotti, 2016). Therefore a certified translator translating a notarial document should not merely transfer the message from the source language (SL) into the target language (TL) which contains legal language, system and culture but he must also render the legal language, system and culture of SL into TL; since the mistake in rendering the message may cause legal consequence to the parties to the contract in the future (Cao, 2007; Sarcevic, 2000).

Based on the aforementioned background, this research is deemed very necessary to find out the issues faced by the certified translators in translating notarial documents and the strategies applied to cope with the problems.

\section{THEORETICAL REVIEW}

The translation of notarial document is categorized as legal translation. It is a specific institutional translation as it closely bound by specific culture (Newmark, 1998) of certain country. Therefore legal translation is considered as the most difficult types of translation (Murici, 2016) and challenging (Müllerová-Shiflett, 2012) as it has its own and particular register and the translators face various legal system between SL and TL (Sarcevic, 2000). It is supported by Rackeviciene \& Sliogeriene, (2014) stating that one of the affecting factors in legal translation is the reality that it is not merely a translation between two or more languages but it is between legal systems and cultures. Thus, the duty of a translator is onerous as he has to be faithful with the intent, style and form of source text (SL) while the message in the TL must be obvious and understandable without any deviation as well as legally acceptable (Zidan, 2015). Because of these particularities, issues and difficulties are inevitable for the translator.

To analyze the issues faced by the translators in translating notarial documents, the idea of Cao (2007) is used. She identified three sources of issues faced by the translators; they are difference of legal system involved, linguistic and cultural difference between SL and TL. While to analyze the strategies applied by the translators of notarial documents, Newmark's strategies are applied. Newmark (1998) proposed 8 translation strategies split into two poles. Four strategies (word-for-word, literal, faithful and semantic translation) are SL-oriented translation and the other four (adaptation, free, idiomatic and communicative translation) are TL-oriented translation. It complied with what he stated that foreign laws are translated for information-specific only, and for such type, Newmark (1998) suggested literal or semantic approach to translation. On the other hand, he also considered that formal register of TL must be observed when handling documents that are to be valid at the same time in the TL society. In this case, according to Newmark's view requires communicative approach (TL-oriented). Although the main theory applied in this research is Newmark's, however it is not impossible for the translators to use other strategies. Therefore, the idea of Molina \& Albir (2002) is also used as the supporting theory.

\section{Methodology}

This research aims at answering two problems. This first problem is the issues faced by the translators and the second one is to find out the strategies used to cope with the issues in translating notarial documents. For the first problem, questionnaires were delivered to 7 translators commonly provided notarial document translation services. Of the 7 questionnaires sent, 5 questionnaires were returned (answered) and the results were further analyzed and discussed in the findings and discussion. To answer the second problem, the researcher used the corpus consisting of ten notarial documents obtained from notary public in charge in four regencies and one city in Bali, Indonesia. The ten notarial documents consist of 3 lease agreements, 2 powers of attorney, 2 prenuptial agreements, and 3 affidavits.

The method applied for this research is descriptive method as it is a product-oriented translation proper (Jakobson in Venuti, 2004). The data is qualitatively analyzed by segmenting the document into segments (term commonly used in Computer Assisted Translation (CAT) Tools to refer to a chunk or a sentence), as described in Table 1.

TABLE I PROCEDURES OF DATA ANALYSIS

\begin{tabular}{|c|l|l|}
\hline Seg. & Source Language (SL) & \multicolumn{1}{c|}{ Target Language (TL) } \\
\hline 1 & $\begin{array}{l}\text { PERJANJIAN SEWA } \\
\text { MENYEWA BANGUNAN }\end{array}$ & $\begin{array}{l}\text { BUILDING LEASE } \\
\text { AGREEMENT }\end{array}$ \\
\hline 2 & \multicolumn{1}{|c|}{ Nomor: 03 } & Number: 03 \\
\hline 3 & $\begin{array}{l}\text {-Pada hari ini, Jum'at tanggal } \\
24-11-2017 \text { (dua puluh empat } \\
\text { Nopember dua ribu tujuh } \\
\text { belas), Pukul 17:30 (tujuh belas } \\
\text { lebih tiga puluh menit) Waktu } \\
\text { Indonesia Tengah; }\end{array}$ & $\begin{array}{l}\text { 2017 (the twenty-fourth day of } \\
\text { November two thousand } \\
\text { seventend At 17:30 (thirty } \\
\text { minutes past seventeen) Middle } \\
\text { Indonesian Time Zone; }\end{array}$ \\
\hline
\end{tabular}

Then, each segment of SL and TL are compared to recognized the translation strategies applied by the translators.

\section{FINDING AND DISCUSSION}

\section{A. Issues encountered by the Translators in Translating Notarial Documents}

Indonesian notarial document as described above is drawn up in Indonesian Language under Indonesian Law. It surely has its own legal system and terminology, as Sarcevic stated that if a legal translation is considered as a communicative act in legal context the background to its law is closely related to the place where the legal system or tradition is produced and enforced as well as the language forming the shape of the legal language (Sarcevic, 2000, p. 56). As a result, such condition causes difficulties to find equivalence in legal terminology between Indonesian language to English. This is a serious issue among legal translators. Further issue is difficulty in finding equivalence in TL. In relation to this lack of equivalence, then Matilla (2006) conveyed two main dangers: void literal translation and misleading literal translation. Void literal translation occurs if a legal concept or institution in TL is meaningless to a foreign party. And the most serious danger is misleading literal translation as it shifts the whole status and function of the legal concept in the TL. 
The result of this research showed that some challenges were encountered by the legal translators in translating Indonesian notarial documents into English. They can be divided into two, namely, linguistics and non-linguistics issues.

\section{1) Linguistics issues}

All respondents reported that they encountered the main problem of finding terminological equivalence between Indonesian notarial documents (SL) and English (TL). For instance, surat kuasa, pemberi kuasa, penerima kuasa, and so forth, are thimbleful terms of art that are difficult for the translators to come across the exact terms in English. Some translators translated surat kuasa into letter of authority, authorization letter and others translated it into power of attorney. So, which is closer to English legal term of art? It is hard to determine. However, from the translated text of the notarial documents most translators opted power of attorney. Similar condition occurs in the collocated terms pemberi kuasa and penerima kuasa. The equivalent legal terms in the TL are even more difficult to find. Some translated them literally into authority giver and authority receiver; some translated them into authorizer and authorizee, and others into grantor and grantee. This issues as David and Brierly (in Cao, 2007) said that the absence of exact equivalence of legal concept and category is the greatest problem in analyzing comparative law. If comparative law is hard to be conducted, its translation is difficult to do.

Syntactic issue is inevitable in the translation of Indonesian notarial documents into English. Indonesian legal Language of notarial document is featured with lengthy and complex sentences. A single sentence is a notary document may be so complex and long, so it looks like a paragraph (Anditya, 2014; Cao, 2007). This lengthy and complex syntactical structure may affect readers' and translators' comprehension and hence makes it difficult in rendering into TL (Anditya, 2014, p.25).

\section{2) Non-Linguistics issues}

There was no report from the respondents with regard to the issues of different legal system between Indonesian and English legal system. It seems that such difference also disembogues and is realized in the difference of terms of art. Relating to the cultural difference, two respondents reported that such difference contributed issues in translation but it is implied in the terminological equivalence. Sarjana Hukum, for instance, as the degree of the notary public is tough to find the exact equivalence. As the result, some translators translated into Law Scholar, some translated it into Bachelor of Law and others into Graduate at Law.

\section{B. Strategies Applied in Notarial Documents Translation}

Two issues have been illustrated above, but, in fact, all the afore issues are involved in the legal terms of art, style and syntax. It has to be carefully observed in the translation of notarial documents. The procedures to cope with these issues in sentence, phrase or even in the word level (Newmark, 1998) is referred to as strategies. To avoid confusion and misleading, in this research, the strategy also includes method of translation, namely, the technique picked up by the translator (Molina \& Albir, 2002) in translating notarial documents. In this research, both terms are considered to have similar definition and used interchangeably. Principally, any methods or strategies can be used in translating notarial documents, but some strategies are applicable and frequently used. In translating practice, a translator may choose one or more appropriate strategies in accordance with to whom and for what purpose the translation of the notarial documents is commissioned.

Based on the result of the research, the strategies applied in translating notarial documents can be distinguished into two, namely, translation strategies in word level and sentence level.

\section{1) Translation Strategies in Word Level}

Each translation expert has his/her own terms in determining the translation strategies, even they often tend to be overlapping between a strategy of one expert to the others, as the same strategies may be differently termed. Of the translated notarial documents, the following strategies were dominantly applied in the translation of notarial documents.

\section{a) Literal Translation}

Literal translation is the basic strategies automatically applied by a translator if appropriate. "If appropriate" means that the meaning or message of SL can be well rendered and the structure of the translation is compatible with the grammatical structure of the TL. In the event that such condition cannot be attained, then other strategies will be selected. It is different from what Alcaraz \& Hughes (2002) stated that they did not recommend literal translation. But, it is not always so. As seen in the example below:

TABLE II LITERAL TRANSLATION STRATEGY

\begin{tabular}{|l|l|}
\hline \multicolumn{1}{|c|}{ Source Language (SL) } & \multicolumn{2}{|c|}{ Target Language (TL) } \\
\hline $\begin{array}{l}\text {-Menghadap kepada saya, ......... } \\
\text { Sarjana Hukum }\end{array}$ & $\begin{array}{l}\text {-Appear before me, } \\
\text { Graduate at Law }\end{array}$ \\
\hline -Tertulis atas nama $\ldots \ldots \ldots$ & -Registered on behalf of \\
\hline Pasal 1 & Article 1 \\
\hline
\end{tabular}

The above examples indicate the words or phrase in SL is word-for-word translated into the TL without any context. The translators only tried to reconstruct the SL structure into the grammatical structure of the TL. In practice, it is commonly acceptable and understandable and the transaction at the Notary Office took place. Thus, what Alcaraz \& Hughes suggested in this example and condition did not work. This strategy is the most frequently used in the notarial document translation.

\section{b) Established equivalence}

This strategy is popular and familiar among translators in notarial document translation. The terms of art used by the translators are commonly found and well accepted by the foreign readers. These terms of art are normally found in the Black Law's Dictionary or in the event such terms are not found, neologism are normally applied but the terms are familiar and well accepted by readers. 
TABLE III ESTABLISHED EQUIVALENCE STRATEGY

\begin{tabular}{|l|l|}
\hline \multicolumn{1}{|c|}{ Source Language (SL) } & \multicolumn{1}{c|}{ Target Language (TL) } \\
\hline $\begin{array}{l}\text { Yang Menyewakan sepakat untuk } \\
\text { menyewakan tanah ... dan Penyewa } \\
\text { sepakat untuk menyewa sebidang .... }\end{array}$ & $\begin{array}{l}\text { The lessor agrees to lease out } \\
\text { the land ... and the lessee agrees } \\
\text { to rent from the lessor a plot of }\end{array}$ \\
\hline $\begin{array}{l}\text { Perjanjian ini dilangsungkan dengan } \\
\text { syarat dan ketentuan sebagai } \\
\text { berikut: }\end{array}$ & $\begin{array}{l}\text { This agreement is entered into } \\
\text { under the terms and conditions } \\
\text { as follows: }\end{array}$ \\
\hline
\end{tabular}

Yang Menyewakan dan penyewa in SL are collocation and then translated into the lessor and the lessee which collocates. The term lessor cannot be found in the dictionary but commonly accepted by the parties in the contract as well as the readers in general as the term collocates with lessee. Similarly, terms and conditions are commonly used in the notarial documents and accepted by the readers. The use of this strategy occupies the second position after literal translation strategy.

\section{c) Calque}

This translation strategy is applied when translating phrase or words of SL into TL literally. Newmark (1998) called this this strategy as through translation or "the literal translation of common collocation, or names of organization. Vinay \& Darbelnet (1995, p. 129) stated that calque is a special kind of borrowing whereby a language borrows an expression form of another, but then translates literally each of its elements, the result is either lexical calque or structural calque. Note that calque uses the expression or structure of SL.

\section{TABLE IV CALQUE STRATEGY}

\begin{tabular}{|l|l|}
\hline Source Language (SL) & Target Language (TL) \\
\hline -Biaya pemeliharaan wajib dibayar & -The costs of maintenance shall be \\
sebelum tanggal 10 setiap bulan & $\begin{array}{l}\text { paid for prior the } 10^{\text {th }} \text { of each } \\
\text { kepada managemen vila. }\end{array}$ \\
month to Villa Management.
\end{tabular}

This translation strategy just transfers the phrase managemen vila into Villa Management by adjusting the spelling and structure of SL into TL.

\section{d) Transference}

The translators used the SL words directly without any changes and adaptation at all. Newmark (1998) stated that transference strategy is used if the equivalence of SL word cannot be found or unknown in TL, or the word refers to a specific place of situation in the SL. It is supported by Molina, \& Albir (2002) that to resolve the unknown concept in TL, borrowing or translation using loan word (Baker, 2001) is the easiest strategies to apply.

\section{TABLE V TRANSFERENCE STRATEGY}

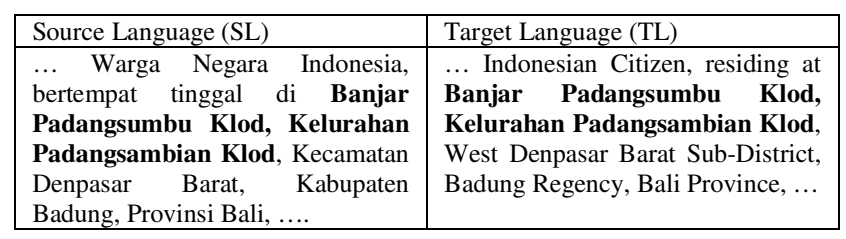

As exemplified above, the transference strategy is used by the translators in translating notarial documents as they cannot find any term having similar or even closer meaning to the term in TL, that's why the translators just picked the SL word purely without any changes or adaptation in the TL as (Hariyanto, 2015; Suryawinata \& Hariyanto, 2016) referred to as transliteration. In this research, this strategy is applied for the level of territory in Indonesia as it is hard to find its equivalence in the TL.

\section{e) Cultural equivalence}

Cultural equivalence is a translation strategy by substituting the cultural words or phrase of SL with the cultural words or phrase of TL (Newmark, 1998, p. 82). The benefit of this strategy is that the translation is easier to be understood and comprehended by the TL readers. The concept, message and condition implied in the SL can be depicted in the TL.

\section{TABLE VI CULTURAL EQUIVALENCE STRATEGY}

\begin{tabular}{|c|c|}
\hline Source Language (SL) & Target Language (TL) \\
\hline $\begin{array}{l}\text {-...para pihak telah memilih tempat } \\
\text { kediaman hukum yang tetap dan } \\
\text { tidak berubah di Pengadilan } \\
\text { Negeri Gianyar. }\end{array}$ & $\begin{array}{l}\text {..the parties have selected a } \\
\text { permanent legal place of domicile } \\
\text { at District Court of Gianyar. }\end{array}$ \\
\hline $\begin{array}{l}\text {-Demikianlah akta ini dibuat pada } \\
\text {... }\end{array}$ & $\begin{array}{l}\text { In witness whereof, this deed is } \\
\text { drawn up at ... }\end{array}$ \\
\hline
\end{tabular}

Foreigners are easier to understand District Court with the assumption that this court is having jurisdiction in the regency level than if it is translated into State Court of Gianyar. And the same case occurs in the translation of demikianlah. If it is translated into "that all" the foreign readers will be confused to comprehend the intended message. Fortunately, the cultural equivalence exists in the TL for demikianlah, so it can be easily understood that this expression is used to close the deed formally.

\section{f) Official Translation}

In official translation strategy, the translators use the terms of art of which use has been officially legalized by a certain institution. The translated terms are usually names of institutions or technical terms used by a certain institution.

\section{TABLE VII OFFICIAL STRATEGY}

\begin{tabular}{|c|c|}
\hline Source Language (SL) & Target Language (TL) \\
\hline $\begin{array}{l}\text {... sebuah perseroan terbatas yang } \\
\text { didirikan menurut Akta Notaris } \\
\text { tertanggal ... }\end{array}$ & $\begin{array}{l}\text {... a limited liability established } \\
\text { under Notarial Deed dated ... }\end{array}$ \\
\hline $\begin{array}{l}\text {... Pajak Penghasilan (PPh) dan } \\
\text { Pajak Pertambahan Nilai (PPN) } \\
\text { akan ditanggung oleh ... }\end{array}$ & $\begin{array}{l}\text { Income Tax and Value-Added } \\
\text { Tax shall be borne and paid for by } \\
\ldots\end{array}$ \\
\hline
\end{tabular}

The above examples are the translations of notarial document applying official translation. Minister of Finance of the Republic of Indonesia has published Indonesian-English official terminology under the Decree number: 914/KMK.01/2016. These terms of art are commonly used in the Ministry of Finance of the Republic of Indonesia, but it is no impossible for other agencies to share these terms of art for their institutions. Other examples are the names of institutions, such as, Ministry of Law and Human Right for Kementrian Hukum dan Hak Azasi Manusia.

\section{2) Translation Strategies in Sentence Level a) Literal Translation}


The literal strategy used by the translator in word level is the same as in sentence level. Applying this strategy, the translators translate the SL of notarial documents without modifying the meaning of the SL. The translators may adjust the grammatical structure of the TL.

TABLE VIII LITERAL TRANSLATION STRATEGY

\begin{tabular}{|l|l|}
\hline \multicolumn{1}{|c|}{ Source Language (SL) } & \multicolumn{1}{c|}{ Target Language (TL) } \\
\hline $\begin{array}{l}\text { Pihak Pertama menjamin Pihak } \\
\text { Kedua bahwa: }\end{array}$ & $\begin{array}{l}\text { The First Party guarantees the } \\
\text { Second Party that: }\end{array}$ \\
\hline $\begin{array}{l}\text { Kedua belah pihak sepakat untuk } \\
\text { menandatangani perjanjian secara } \\
\text { sah ... }\end{array}$ & $\begin{array}{l}\text { Both parties have agreed to sign an } \\
\text { agreement legally ... }\end{array}$ \\
\hline
\end{tabular}

From the segment above, it is clear that the translator only renders the SL sentence into English. No modification was made by the translator in term of meaning. This result of this translation strategy seems unnatural and therefore not recommended but it is acceptable and comprehendible. Even this translation strategy is mostly applied by translators in translating Indonesian notarial document into English.

\section{b) Transposition strategy}

This translation strategy is used in translating clauses or sentences. This strategy is applied upon the reason of style. It includes change of plural to singular form to structural change of sentence (Newmark, 1998, p. 85). The split of a sentence or joining two sentences or more into one sentence includes in this strategy. Under this strategy, the translators translate sentences in different grammatical structure of SL but has similar semantic density.

\section{TABLE IX TRANSPOSITION STRATEGY}

\begin{tabular}{|l|l|}
\hline \multicolumn{1}{|c|}{ Source Language (SL) } & \multicolumn{1}{c|}{ Target Language (TL) } \\
\hline $\begin{array}{l}\text { Para penghadap telah saya, Notaris } \\
\text { kenal; }\end{array}$ & $\begin{array}{l}\text { The appearers have been known by } \\
\text { me, Notary; }\end{array}$ \\
\hline $\begin{array}{l}\text { Bahwa di atas tanah tersebut } \\
\text { sedang dilakukan pembangunan } \\
\text { beberapa buah bangunan vila. }\end{array}$ & $\begin{array}{l}\text { Whereas, several units of villas are } \\
\text { being developed on the said land. }\end{array}$ \\
\hline
\end{tabular}

From the example above, the translator changed the structure of the SL sentence in TL sentence. The SL sentence structure is in active form while the structure in the TL is in passive form. In the later example, both SL and TL sentence are in passive form, but there is different focus between SL and TL. SL focuses on the land while TL focuses on several units of villas.

\section{c) Adaptation}

Due to different background between SL and TL, the equivalence expression or concept of SL is frequently difficult to find (Bell, 1991, p. 71). In this case, the strategy used by the translators is the use of equivalence expression or words commonly used in the same circumstance to translate an expression or words.

\section{TABLE X ADAPTATION STRATEGY}

\begin{tabular}{|l|l|}
\hline Source Language (SL) & Target Language (TL) \\
\hline Demikianlah akta ini, ... & In witness whereof, ... \\
\hline $\begin{array}{l}\text { Menghadap kepada saya, ..., } \\
\text { Sarjana Hukum }\end{array}$ & $\begin{array}{l}\text { Appear before me, ..., Graduate at } \\
\text { Law }\end{array}$ \\
\hline $\begin{array}{l}\text { Selanjutnya di dalam akta ini } \\
\text { disebut sebagai Pihak Pertama }\end{array}$ & $\begin{array}{l}\text { Hereinafter in this deed is referred } \\
\text { to as the First Party }\end{array}$ \\
\hline
\end{tabular}

Of the above examples, the translators use TL equivalence expressions commonly used by the foreigners for the SL expressions or concept. The exact equivalence for demikianlah, menghadap kepada saya, and selanjutnya di dalam akta ini disebut sebagai Pihak Pertama are not in witness whereof, appear before me, hereinafter in this deed ... respectively, however these expressions are commonly used by the translators and well understood and comprehended by the foreign users.

\section{CONCLUSION}

Translators encountered some issues in translating notarial documents, such as, linguistic and non-linguistic issues but they did not realize that the linguistic issues faced were derived from different legal system and culture between SL and TL. To cope with such issues, some translation strategies were used, namely, literal translation, established translation, calque, transference, cultural translation and official translation in word level, while in sentence level, literal translation, transposition and adaptation translation were applied.

\section{Acknowledgment}

We thank very much for Budiono, SH., M.Kn, the Notary Public of Badung Regency for his great help to procure Notarial documents. And thanks is also forwarded to all translators for the kindness in answering and returning the questionnaires.

\section{References}

Alcaraz, E., \& Hughes, B. (2002). Legal translation explained. New York: St. Jerome.

Anditya, D. S. Des. (2014). Translation techniques and equivalence in the Indonesian translation of Asean Charter. Diponegoro University.

Baker, M. (2001). In Other Words: A course book on translation (e-Library). London and New York: Routledge.

Bell, R. T. (1991). Theory of translation. London and New York: Longman.

Cao, D. (2007). Translating law. (S. Bassnett \& E. Gentzler, Eds.). Clevedon: Multilingual Matters Ltd. Retrieved from http://www.multilingual-matters.com

Gotti, M. (2016). The translation of legal texts: Interlinguistic and intralinguistic perspectives. Journal of English for Specific Purposes at Tertiary Level, 4(1), 5-21.

Hariyanto, S. (2015). Website translation (2nd Ed.). Malang: Penerbit Inspira.

Kocbek, A. (2012). An integrated model for translating legal texts. Vertimo Studijos, 5, 64-75.

Matilla, H. E. (2006). Comparative legal Linguistics. Burlington: Ashgate Publishing Company.

Molina, L., Albir, A. H. (2002). Translation techniques revisited. Meta: Journal Des Traducteurs, 47(4), 499512.

Müllerová-Shiflett, M. (2012). Functional equivalence and its 
role in legal translation. English Matters.

Murici, M. (2016). Issues in translating legal text. International Journal of English Language \& Translation Studies, 4(3), 69-74. Retrieved from www.eltsjournal.org

Newmark, P. (1998). A text of translation. Hertfordshire: Prentice Hall.

Rackeviciene, S., \& Sliogeriene, J. (2014). Dealing with nonequivalence of legal terminology-A comparative case study of Lithuanian and English legal terms. English For Specific World, 15(42). Retrieved from www.espworld.info

Sarcevic, S. (2000). New approach to legal translation. The Hague - London - Boston: Kluwer Law International.

Suryawinata, Z., \& Hariyanto, S. (2016). Translation, bahasan teori \& penuntun praktis menerjemahkan (Revisi). Yogyakarta: Penerbit Kanisius.

Venuti, L. (2004). The translation studies readers. (V. Lawrence, Ed.) (2nd). London and New York: Routledge.

Zidan, A. A. Y. M. (2015). A linguistic analysis of some problems of Arabic-English translation of legal text, with special reference to contracts (Pertama). Cambridge: Cambridge Scholars Publishing. 